\title{
New types of one-dimensional discrete breathers in a two-dimensional lattice
}

\author{
A.S. Semenov ${ }^{1}$, R. T. Murzaev², Yu. V. Bebikhov ${ }^{1}$, A. A. Kudreyko³, S. V. Dmitriev ${ }^{\dagger, 2,4}$ \\ †dmitriev.sergey.v@gmail.com \\ ${ }^{1}$ Mirny Polytechnic Institute (branch) of North-Eastern Federal University, 5 Tikhonova St., Mirny, 678174, Russia \\ ${ }^{2}$ Institute for Metals Superplasticity Problems RAS, 39 S. Khalturin St., Ufa, 450001, Russia \\ ${ }^{3}$ Department of Medical Physics and Informatics, Bashkir State Medical University, 3 Lenina St., Ufa, 450008, Russia \\ ${ }^{4}$ Institute of Molecule and Crystal Physics UFRC RAS, 71 Oktyabrya Av., Ufa, 450054, Russia
}

Discrete breather (DB) is a spatially localized and periodic in time, large-amplitude vibrational mode in a nonlinear lattice. According to some experimental and a number of molecular dynamics studies, crystal lattices support various types of DBs. The final goal in the study of DBs is to understand their impact on macroscopic crystal properties. This aim cannot be achieved without further data collection on the properties of all types of DBs supported by the crystals. Recently $k$-dimensional DBs in $n$-dimensional crystal lattices $(k<n)$ have been introduced. Such DBs are delocalized in $k$ dimensions and localized in $n-k$ dimensions. In the present study $2 \mathrm{D}$ triangular lattice with the classical Lennard-Jones potential is considered $(n=2)$ and new types of one-dimensional DBs $(k=1)$ are presented. The DBs are localized in one close-packed atomic row and the vibration amplitudes of the atoms decrease exponentially with the distance from this row. Quite general approach for excitation of such DBs is used, which is based on the delocalized nonlinear vibrational modes (DNVMs) derived by Chechin with co-authors for a nonlinear chain. We find that DNVMs reported by them produce one-component and two-component, one-dimensional DBs with relatively long lifetime in the triangular lattice. Our results contribute to the theory of nonlinear lattice dynamics and eventually will help to understand the role of DBs in crystalline solids.

Keywords: crystal lattice, nonlinear lattice dynamics, discrete breather, delocalized nonlinear vibrational mode, molecular dynamics.

УДК: 539

\section{Новые типы одномерных дискретных бризеров в двумерной решетке}

\author{
Семенов А. С. ${ }^{1}$, Мурзаев Р.Т. ${ }^{2}$, Бебихов Ю. В. ${ }^{1}$, Кудрейко А. А. ${ }^{3}$, Дмитриев С. В. ${ }^{\dagger 2,4}$ \\ ${ }^{1}$ Мирнинский политехнический институт (филиал) Северо-Восточного федерального университета, \\ ул. Тихонова, 5, Мирный, 678174, Россия \\ ${ }^{2}$ Институт проблем сверхпластичности металлов РАН, ул. С. Халтурина, 39, Уфа, 450001, Россия \\ ${ }^{3}$ Кафедра Медицинской физики с курсом информатики, Башкирский государственный медицинский университет, \\ ул. Ленина, 3, Уфа, 450008, Россия \\ ${ }^{4}$ Институт физики молекул и кристаллов УФИЦ РАН, пр. Октября, 71, Уфа, 450054, Россия
}

Дискретный бризер (ДБ) - это пространственно локализованная и периодическая по времени колебательная мода большой амплитуды в нелинейной решетке. Согласно ряду экспериментальных и молекулярно-динамических исследований, кристаллические решетки поддерживают различные типы ДБ. Конечная цель изучения ДБ - понять их влияние на макроскопические свойства кристаллов. Эта цель не может быть достигнута без дальнейшего сбора данных о свойствах всех типов ДБ, поддерживаемых кристаллами. Недавно были введены $k$-мерные ДБ в $n$-мерных кристаллических решетках $(k<n)$. Такие ДБ делокализованы в $k$ измерениях и локализованы в $n-k$ измерениях. В настоящей работе рассматривается двумерная треугольная решетка с классическим потенциалом Леннарда-Джонса $(n=2)$ и представлены новые типы одномерных ДБ $(k=1)$. ДБ локализованы в одном плотно упакованном атомном ряду, и амплитуды колебаний атомов экспоненциально уменьшаются с расстоянием 
от этого ряда. Для возбуждения таких ДБ используется довольно общий подход, основанный на делокализованных нелинейных колебательных модах (ДНКМ), полученных Чечиным с соавторами для нелинейной цепочки. Мы обнаружили, что найденные ими ДНКМ создают однокомпонентные и двухкомпонентные одномерные ДБ с относительно большим временем жизни в треугольной решетке. Наши результаты вносят вклад в теорию нелинейной динамики решетки и, в конечном итоге, помогут понять роль ДБ в кристаллических твердых телах.

Ключевые слова: кристаллическая решетка, нелинейная динамика решетки, дискретный бризер, делокализованная нелинейная колебательная мода, молекулярная динамика.

\section{Introduction}

Some thirty years ago it has been shown that defect-free nonlinear lattices admit energy localization in the form of discrete breathers (DBs), synonymously called intrinsic localized modes (ILMs) [1-3]. DBs have been studied theoretically and experimentally in a diversity of physical systems [4] and also in various crystals [5] including carbon and hydrocarbon structures [6-14], boron nitride [15], ionic [16-18] and covalent $[19,20]$ crystals, ordered alloys [21-23], pure metals [24-30], metal hydrides [31], etc. It is very important to study $\mathrm{DB}$ properties because they affect defect structure of crystalline solids [28] and their macroscopic characteristics such as heat capacity [32], thermal expansion [33], and thermal conductivity [34,35]. DBs can be important in tribological applications [36].

According to the definition, DBs are spatially localized vibrational modes in nonlinear lattices. Obviously, in a $n$-dimensional lattice $\mathrm{DB}$ can be localized not in all $n$ dimensions but in $k<n$ dimensions. For the first time this idea was expressed by Baimova in the work [37], where one-dimensional DBs were analyzed in two-dimensional lattice of graphene (the case of $k=1, n=2$ ). Later, in pure fcc metals, linear $(k=1, n=3)$ and planar $(k=2, n=3)$ DBs were identified by Bachurina $[25,26]$. In her works, the delocalized nonlinear vibrational modes (DNVMs) were successfully used for setting initial conditions for DB excitation. Note that DNVMs (also termed as the bushes of normal nonlinear modes [38-40]) are high-amplitude delocalized vibrational modes that are exact solutions of nonlinear dynamic equations due to the point symmetry of the crystal lattice. Dynamics of a DNVM can be fully described by $N$ coupled equations of motion, and such vibrational mode is called $\mathrm{N}$-component DNVM. If the frequency of a DNVM leaves the phonon spectrum with increasing amplitude, then a localizing function can be used to obtain a DB. This approach turned out to be very effective for excitation of discrete breathers not only in fcc metals $[25,26]$ but also in a two-dimensional Morse crystal $[41,42]$ and in graphene [43].
In the present study we use the one- and two-component DNVMs derived in [39] for a one-dimensional lattice (chain of coupled particles) in order to excite one-dimensional DBs in a close-packed atomic row of 2D triangular lattice $(k=1$, $n=2)$.

\section{Methodology}

A triangular two-dimensional lattice with an interatomic distance $d$ is considered. The $x$ axis of the Cartesian coordinate system is directed along closely packed atomic rows. Atoms interact via the classical Lennard-Jones potential

$$
U_{L J}(r)=L\left[\left(\frac{r_{l}}{r}\right)^{12}-2\left(\frac{r_{l}}{r}\right)^{6}\right],
$$

with the parameters $L$ and $r_{l}$. The first one defines the binding energy, while the second one - the equilibrium distance for a pair of interacting atoms. Without the loss in generality, we take $L=1, r_{l}=1$, and the atom mass $M=1$, which can always be achieved by a proper choice of the units for length, energy and time, respectively. The cut-off radius is $5 r_{l}$, then the equilibrium interatomic distance is $d=0.99027777$. The equations of motion of atoms were integrated using the Stormer method of sixth order of accuracy with a time step equal to $\tau=10^{-3}$. No thermal vibrations were introduced, that is, modeling was carried out at a temperature of $0 \mathrm{~K}$. Periodic boundary conditions were used. The computational cell size is $12 \times 60$ atoms ( 12 atoms along the $x$ axis and 60 close-packed atomic rows along the $y$-axis).

The initial conditions are as follows. Initial displacements along the $x$-axis are given to the atoms of single close-packed row parallel to the $x$-axis. All other atoms have zero initial displacements and all the atoms in the computational cell have zero initial velocities. The patterns of initial displacements for the studied seven DNVMs are listed in Table 1, taking the results form [39]. We consider four 1-component and three 2-component DNVMs. Displacement pattern in DNVMs has

Table 1. Patterns of initial displacements applied to the atoms of a close-packed atomic row of the triangular lattice. One period of the patterns is given.

\begin{tabular}{|c|c|c|c|}
\hline DNVM number & Displacement pattern & Period $(p)$ & Number of DNVM components $(N)$ \\
\hline 1 & {$[x,-x]$} & 2 & 1 \\
\hline 2 & {$[x, 0,-x]$} & 3 & 1 \\
\hline 3 & {$[0, x, 0,-x]$} & 4 & 1 \\
\hline 4 & {$[x, x,-x,-x]$} & 4 & 2 \\
\hline 5 & {$\left[x_{1}, x_{2}, x_{3}\right], x_{1}+x_{2}+x_{3}=0$} & 3 & 2 \\
\hline 6 & {$\left[x_{1}, x_{2},-x_{2},-x_{1}\right]$} & 4 & 2 \\
\hline 7 & {$\left[x_{1},-x_{1}, x_{2},-x_{2}\right]$} & 4 & 1 \\
\hline
\end{tabular}


period $p$. This size of the computational cell along the $x$ axis is compatible with the 2-, 3-, and 4-periodic DNVMs excited in a close-packed row parallel to the $x$-axis, since 2, 3 and 4 are divisors of 12 .

\section{Numerical results}

In Fig. 1, as the functions of time, we plot the $x$-components of displacements, $\Delta x_{i}$, for the atoms in the initially excited close-packed atomic row. For the DNVM with period $p$ displacements of $p$ neighboring atoms are plotted. In all cases the initial displacement was equal to 0.2 .

Note that all four one-component DNVMs are periodic in time. DNVM-1 shown in Fig. 1a is a well-known zoneboundary mode, which has been used for excitation of one-dimensional DBs in fcc metals [25] and in a number of other works, e.g., in [45]. Other one-component DNVMs, to the best of our knowledge, have not been analyzed in the lattices of dimension greater than 1 .

In Fig. 2, for the three two-component DNVMs 5 to 7, we present the same data as in Fig. 1. It can be seen that the atomic oscillations in the two-component DNVMs are not periodic, which is the sequence of the interaction between the two components. On the other hand, other harmonics are not excited, as it follows from the general theory of the bushes of normal modes [38-40]. Thus, the three two-component DNVMs of the one-dimensional lattice produce three new one-dimensional DBs in the $2 \mathrm{D}$ triangular lattice.
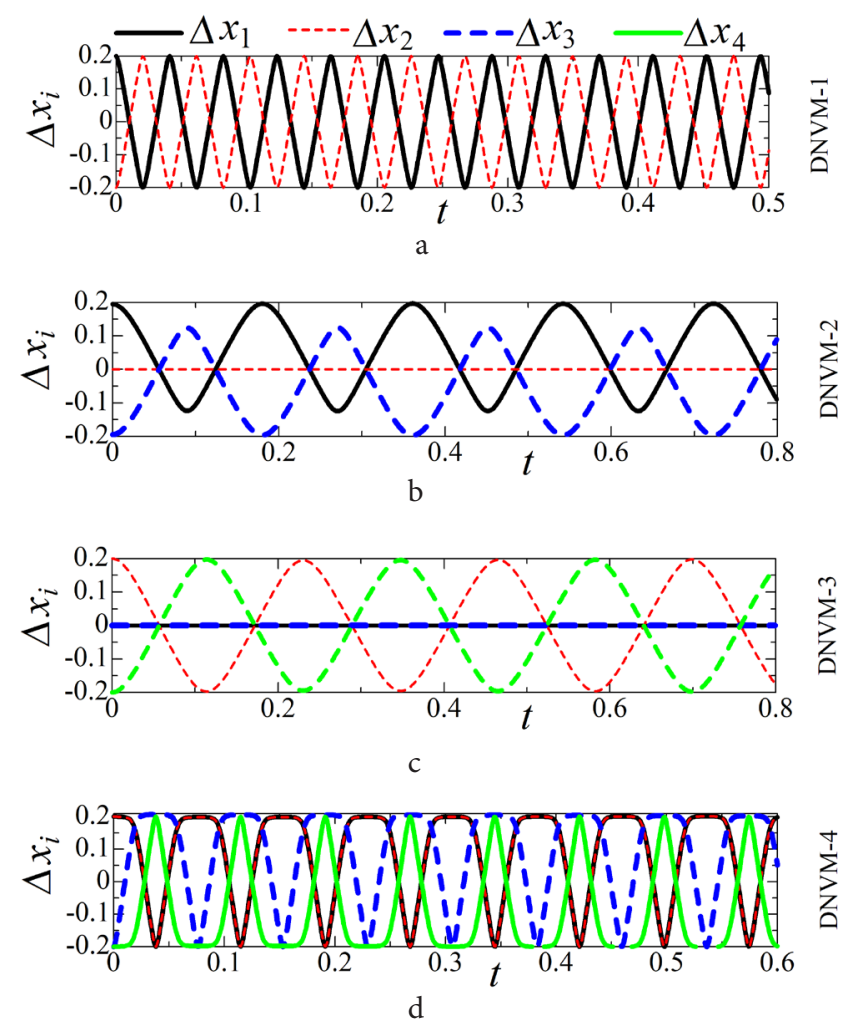

Fig. 1. (Color online) Displacements of atoms as the functions of time for one-component DNVMs 1 to 4, respectively. Initial displacement of atoms equals to 0.2 for all four DNVMs. Only displacements of atoms belonging to one translational cell are shown. Curves of different type are used for different atoms, as specified at the top of the figure (a) - (d).
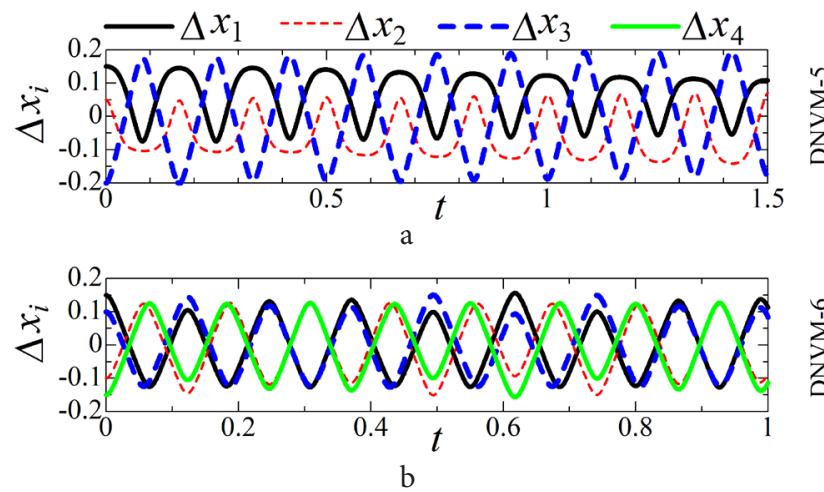

$\sum_{\substack{1 \\ 0}}^{1}$

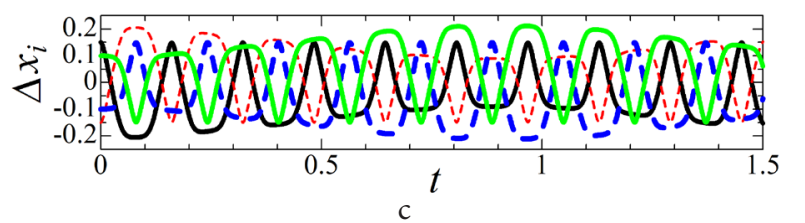

Fig. 2. (Color online) Same as in Fig. 1, but for the three twocomponent DNVMs 5 to 7 . Initial displacement of atoms are equal to $x_{1}=0.15, x_{2}=0.05, x_{3}=-0.2(\mathrm{a}) ; x_{1}=0.15, x_{2}=0.1(\mathrm{~b}) ; x_{1}=0.15$, $x_{2}=0.1(\mathrm{c})$.

It should be pointed out that DNVMs with the amplitude above a threshold value are unstable [44-49]. Here dynamics of unstable one- and two-component DNVMs is presented before the instability is developed.

\section{Conclusions}

New types of one-dimensional DBs in two-dimensional triangular lattice are identified with the use of the one- and two-component DNVMs derived by Chechin et al. for onedimensional lattice [39]. The reported DBs are localized in a close-packed atomic row of the triangular lattice. One of the one-dimensional DBs based on the zone-boundary DNVM has been reported earlier in fcc metals [25], and all other one-dimensional DBs, to the best of our knowledge, are new. As expected, one-dimensional DBs based on the one-component DNVMs demonstrate periodic in time oscillations. On the other hand, DBs based on the two-component DNVMs are aperiodic due to the energy exchange between two components.

Present study opens the road for investigation of new one-dimensional DBs in a variety of crystals including fcc, bcc and hcp metals.

Acknowledgements. A.S. Semenov acknowledges the financial support provided by the Russian Foundation for Basic Research, grant No. 18-32-00171 (simulations). S. V. Dmitriev thanks the Russian Foundation for Basic Research, grant No. 19-02-00971 (manuscript writing). The work was partly supported by the State Assignment of IMSP RAS No. AAAAA17-117041310220-8.

\section{References}

1. A. S. Dolgov. Sov. Phys. Solid State. 28, 907 (1986).

2. A. J. Sievers, S. Takeno. Phys. Rev. Lett. 61, 970 (1988).Crossref

3. J. B. Page. Phys. Rev. B. 41, 7835 (1990). Crossref

4. S. Flach, C. R. Willis. Phys. Rep. 295, 181 (1998). Crossref 
5. S.V. Dmitriev, E.A. Korznikova, J.A. Baimova, M. G. Velarde. Phys. Usp. 59, 446 (2016). Crossref

6. T. Shimada, D. Shirasaki, T. Kitamura. Phys. Rev. B. 81, 035401 (2010). Crossref

7. Y. Yamayose, Y. Kinoshita, Y. Doi, A. Nakatani, T. Kitamura. Europhys. Lett. 80, 40008 (2007). Crossref

8. Y. Kinoshita, Y. Yamayose, Y. Doi, A. Nakatani, T. Kitamura. Phys. Rev. B. 77, 024307 (2008). Crossref

9. B. Liu, J. A. Baimova, S. V. Dmitriev, X. Wang, H. Zhu, K. Zhou. J. Phys. D: Appl. Phys. 46, 305302 (2013). Crossref

10. G. M. Chechin, S. V. Dmitriev, I. P. Lobzenko, D. S. Ryabov. Phys. Rev. B. 90, 045432 (2014). Crossref

11. L. Z. Khadeeva, S. V. Dmitriev, Y. S. Kivshar. JETP Lett. 94, 539 (2011). $\underline{\text { Crossref }}$

12. J.A. Baimova, S. V. Dmitriev, K. Zhou. Europhys. Lett. 100, 36005 (2012). Crossref

13. I.P. Lobzenko, G.M. Chechin, G.S. Bezuglova, Yu. A. Baimova, E. A. Korznikova, S. V. Dmitriev. Phys. Solid State. 58, 633 (2016). Crossref

14. I. Evazzade, I. P. Lobzenko, E. A. Korznikova, I. A. Ovid'Ko, M. R. Roknabadi, S. V. Dmitriev. Phys. Rev. B. 95, 035423 (2017). Crossref

15. E. Barani, E. A. Korznikova, A. P. Chetverikov, K. Zhou, S. V. Dmitriev. Phys. Lett. A. 381, 3553 (2017). Crossref

16. S. A. Kiselev, A. J. Sievers. Phys. Rev. B. 55, 5755 (1997). Crossref

17. L.Z. Khadeeva, S. V. Dmitriev. Phys. Rev. B. 81, 214306 (2010). Crossref

18. A. Riviere, S. Lepri, D. Colognesi, F. Piazza. Phys. Rev. B. 99, 024307 (2019). Crossref

19. N.K. Voulgarakis, G. Hadjisavvas, P.C. Kelires, G. P. Tsironis. Phys. Rev. B. 69, 113201 (2004). $\underline{\text { Crossref }}$

20. R. T. Murzaev, D. V. Bachurin, E.A. Korznikova, S. V. Dmitriev. Phys. Lett. A. 381, 1003 (2017). Crossref

21. N.N. Medvedev, M.D. Starostenkov, M.E. Manley. J. Appl. Phys. 114, 213506 (2013). Crossref

22. M.D. Starostenkov, A.I. Potekaev, S.V. Dmitriev, P. V. Zakharov, A. M. Eremin, V. V. Kulagina. Russ. Phys. J. 58, 1353 (2016). Crossref

23. P.V. Zakharov, E.A. Korznikova, S.V. Dmitriev, E. G. Ekomasov, K. Zhou. Surf. Sci. 679, 1 (2019). Crossref

24. M. Haas, V. Hizhnyakov, A. Shelkan, M. Klopov, A. J. Sievers. Phys. Rev. B. 84, 144303 (2011). Crossref

25. O.V. Bachurina. Comp. Mater. Sci. 160, 217 (2019). Crossref

26. O. V. Bachurina. Model. Simul. Mater. Sci. Eng. 27, 055001 (2019). Crossref

27. R. T. Murzaev, A. A. Kistanov, V.I. Dubinko, D. A. Terentyev, S. V. Dmitriev. Comp. Mater. Sci. 98, 88 (2015). Crossref

28. D.A. Terentyev, A.V. Dubinko, V.I. Dubinko, S. V. Dmitriev, E. E. Zhurkin, M. V. Sorokin. Model. Simul.
Mater. Sc. 23, 085007 (2015). Crossref

29. R. T. Murzaev, R. I. Babicheva, K. Zhou, E. A. Korznikova, S. Y. Fomin, V. I. Dubinko, S. V. Dmitriev. Eur. Phys. J. B. 89, 168 (2016). Crossref

30. O.V. Bachurina, R.T. Murzaev, A.S. Semenov, E. A. Korznikova, S. V. Dmitriev. Phys. Solid State. 60, 989 (2018). Crossref

31. V. Dubinko, D. Laptev, D. Terentyev, S. V. Dmitriev, K. Irwin. Comp. Mater. Sci. 158, 389 (2019). Crossref

32. B. Mihaila, C.P. Opeil, F. R. Drymiotis, J. L. Smith, J.C. Cooley, M.E. Manley, A. Migliori, C. Mielke, T. Lookman, A. Saxena, A. R. Bishop, K. B. Blagoev, D. J. Thoma, J.C. Lashley, B.E. Lang, J. Boerio-Goates, B. F. Woodfield, G. M. Schmiedeshoff. Phys. Rev. Lett. 96, 076401 (2006). $\underline{\text { Crossref }}$

33. M.E. Manley. Acta Mater. 58, 2926 (2010). Crossref

34. D. Xiong, D. Saadatmand, S. V. Dmitriev. Phys. Rev. E. 96, 042109 (2017). Crossref

35. J. Wang, S. V. Dmitriev, D. Xiong. Phys. Rev. Research. 2, 013179 (2020). Crossref

36. V. Popov. Facta Universitatis, Series: Mechanical Engineering. 17, 39 (2019). Crossref

37. J. Baimova. Letters on Materials. 6, 31 (2016). Crossref

38. G. M. Chechin, V.P. Sakhnenko. Physica D. 117, 43 (1998). $\underline{\text { Crossref }}$

39. G. M. Chechin, D.S. Ryabov, K. G. Zhukov. Physica D. 203, 121 (2005). Crossref

40. G. M. Chechin, D. S. Ryabov, S. A. Shcherbinin. Letters on Materials. 6 (1), 9 (2017). Crossref

41. S. Yu. Fomin, E.A. Korznikova. Letters on Materials. 6 (1), 57 (2016). Crossref

42. A. A. Kistanov, A. S. Semenov, S. V. Dmitriev. J. Exp. Theor. Phys. 119, 766 (2014). Crossref

43. E. Barani, I. P. Lobzenko, E. A. Korznikova, E. G. Soboleva, S. V. Dmitriev, K. Zhou, A. M. Marjaneh. Eur. Phys. J. B. 90, 38 (2017). Crossref

44. D.U. Abdullina, M.N. Semenova, A.S. Semenov, E. A. Korznikova, S. V. Dmitriev. Eur. Phys. J. B. 92, 249 (2019). Crossref

45. V. M. Burlakov, S. Kiselev. Sov. Phys. JETP. 72, 854 (1991).

46. K. Ikeda, Y. Doi, B. F. Feng, T. Kawahara. Physica D. 225, 184 (2007). $\underline{\text { Crossref }}$

47. E. A. Korznikova, D.V. Bachurin, S. Yu. Fomin, A. P. Chetverikov, S. V. Dmitriev. Eur. Phys. J. B. 90, 23 (2017). Crossref

48. S.A. Shcherbinin, M.N. Semenova, A.S. Semenov, E. A. Korznikova, G. M. Chechin, S. V. Dmitriev. Phys. Solid State. 61, 2139 (2019). Crossref

49. O.V. Bachurina, R.T. Murzaev, D. V. Bachurin. Journal of Micromechanics and Molecular Physics. 04, 1950001 (2019). Crossref 